\title{
Evaluation of a technique for measuring canopy volume of shrubs
}

\author{
MARK S. THORNE, QUENTIN D. SKINNER, MICHAEL A. SMITH, J. DANIEL RODGERS, WILLIAM A. \\ LAYCOCK, AND SULE A. CEREKCI
}

\begin{abstract}
Authors are Graduate Research Assistant, Department of Rangeland Ecosystem Science, Colorado State University, Fort Collins, Colo, Professors, Assistant Professor, and Professor Emeritus, Department of Renewable Resources, University of Wyoming, Laramie, Wyo., and Project Engineer, Ministry of Agriculture and Rural Affairs, Eastern Anatolia Watershed Rehabilitation Project, Turkey. At the time of research, the senior author was a Graduate Research Assistant, Department of Renewable Resources, University of Wyoming, Laramie, Wyo.
\end{abstract}

\begin{abstract}
Cover methods quantify vegetative communities in only 2 dimensions. The addition of height measurements to cover data, resulting in canopy volume estimates, provide a more practical level of description for shrub communities. We evaluated a technique to estimate canopy volume of shrubs that used a formula $[2 / 3 \pi H(A / 2 \times B / 2)]$ derived from the basic ellipsoid volume formula. Objectives of this study were to determine if there were significant differences among means of repeated observations on sample units: (1) among observers; (2) within observers; and (3) between sample periods when using this technique. At 2 locations in Wyoming, 10 planeleaf willow (Salix planifolia var. planifolia Pursh) plants along each of 5 randomly established transects were sampled during 2 consecutive periods by 4 observers. Differences among observers were significant at both sites $(P<$ 0.05). However, within observer variation between sample periods was not significant $(P>0.05)$ at either site. Mean canopy volume did not vary significantly $(P>0.05)$ between sample periods when averaged across observers. Estimated sample sizes ranged between 2 and 31 transects depending on the desired sampling precision and confidence level. The average time per transect among all observers decreased from 13 minutes $(\mathrm{SD}=3.7)$ in sample period 1 to 9 minutes $(S D=1.3$ ) in sample period 2. Using this method, managers can better describe and monitor trends in the structural diversity of shrub communities. This canopy volume technique can be applied with minimal training and is precise, efficient, and repeatable.
\end{abstract}

Key Words: willow (Salix spp.), measurement variability, sampling techniques, sample size

Early researchers realized that temporal changes in plant cover were often a reflection of management practices and developed appropriate techniques to quantify those changes (Nelson 1930, Pickford and Stewart 1935, Bauer 1936, Parker 1951, Cooper 1957, Daubenmire 1959). Other investigators noted that plant

Research was funded in part by the Wyoming Water Resources Center, the Hyatt Ranch, the Pitchfork Ranch, the WesMar Grazing Management Trust Fund and the SRM Hyatt Trust. Authors wish to thank Dr. Robert S. Cochran of the Statistics Department at the University of Wyoming for assistance in statistical analyses. We would also like to thank Dr. J. Brummer and 2 anonymous reviewers for their insightful comments and suggestions on drafts of this manuscript.

Manuscript accepted 22 Aug. 01.

\section{Resumen}

Los métodos de cobertura cuantifican las comunidades vegetativas en solo 2 dimensiones. La adición de mediciones de altura a los datos de cobertura resultan en estimaciones del volumen de la copa y proveen un nivel más práctico de descripción de las comunidades de arbustos. Evaluamos una técnica para estimar el volumen de copa de los arbustos que utiliza una fórmula [ $2 / 3 \pi H(A / 2 \times B / 2)]$ derivada de la fórmula básica para calcular el volumen de un elipsoide. Los objetivos de este estudio fueron determinar si hubo diferencias significativas entre las medias de observaciones repetidas en unidades de muestreo: (1) entre observadores; (2) dentro de observadores y (3) entre periodos de muestreo cuando se utiliza esta técnica. En 2 localidades de Wyoming, 10 plantas de "Planeleaf willow" (Salix planifolia var. planifolia Pursh), situadas a lo largo de cada uno de 5 transecto establecidos aleatoriamente, se muestrearon por 4 observadores durante 2 periodos consecutivos. Las diferencias entre observadores fueron significativas en ambos sitios $(P<0.05)$. Sin embargo, la variación dentro de observadores entre los periodos de muestro no fue significativa $(P>0.05)$ en ningún sitio. Cuando la media del volumen de la copa se promedio entre observadores esta no varió significativamente $(P>0.05)$ entre los periodos de muestreo. Los tamaños de muestra estimados variaron entre 2 y 31 transecto, dependiendo de la precisión de muestreo y nivel de confianza deseados. El tiempo promedio por transecto entre todos los observadores disminuyó de 13 minutos (DS = 3.7) en el periodo de muestreo 1 a 9 minutos $(D S=1.3)$ en el periodo de muestreo 2 . Usando este método los manejadores pueden describir y monitorear mejor las tendencias en la diversidad estructural de las comunidades de arbustos. Esta técnica de volumen de copa puede ser aplicada con un entrenamiento mínimo y es precisa, eficiente $y$ repetible.

cover estimates varied between methods, observers, and vegetation types (Smith 1944, Johnston 1957, Heady et al. 1959 , Kinsinger et al. 1960, Fisser 1961). Despite problems with precision, repeatability, and efficiency, these methods remain in common use.

Cover methods quantify vegetative communities in only 2 dimensions. Daubenmire (1968) noted that the omission of the vertical dimension was the largest limitation to cover data. $\mathrm{He}$ also pointed out that, since height was a structural parameter, it could be used to determine and compare dominance of plant species in a community. Zamora (1981) modified Daubenmire's 
(1959) quadrat frame with the addition of a vertical dimension and suggested that it could be used to quantify canopy volume in shrub communities. Recently, Myers (1989) suggested that the addition of height measurements might be a more practical level of description for riparian shrub communities. In addition, canopy volume estimates have been used for predicting biomass or current-year twig production of shrubs (Lyon 1968, Peek 1970, Rittenhouse and Sneva 1977, Uresk et al. 1977, Bryant and Kothmann 1979, Creamer 1991).

More recently, several investigators have used canopy volume to quantify other attributes of shrub communities. For example, Taylor (1986) used canopy volume to define nesting habitat suitability for passerine birds in willow (Salix spp.) communities along the Blitzen River in Oregon. Manoukian (1994) used canopy volume to describe seasonal changes in Montana willow communities subjected to wildlife and livestock herbivory.

Although prior studies have focused on estimating plant volume, all used different measures of the volume components. Likewise, a variety of mathematical formulas have been used to calculate volume. Therefore, comparing canopy volume estimates among different studies and management programs is difficult. Since canopy volume is an important attribute in shrub communities and its estimation is becoming more common, it may be appropriate to standardize an approach to measure it. It would also be convenient to use a mathematical formula that is elastic in its ability to absorb a wide range of canopy shapes. Several factors could define the usefulness of a standard method of measuring canopy volume such as ease of application, efficiency, precision, and repeatability.

Ease of application is related to the simplicity of the methodology. Efficiency is a function of the time it takes to make a precise and repeatable estimate where as, precision and repeatability of an estimate are controlled by the inherent variation in the vegetative community and error caused by the method and observer. Error imposed by the method and variation in the vegetative community are uncontrollable. Since vegetative communities are the object of study, controlling this source of variation in the estimate is only desirable for sources not related to the community or temporal factors of interest. Conversely, error in accuracy imposed by a method designed to measure vegetative attributes is always undesirable. If a method (assuming no observer error) continuously overor underestimates an attribute of interest, then it is a less desirable technique.

\section{Canopy Volume Formula}

In estimating plant canopy volumes, the largest source of methodological error lies in the volume formula. Lyon (1968), Peek (1970), Creamer (1991), and Manoukian (1994) used mathematically equivalent formulas for an elliptical cylinder to estimate canopy volume of different shrub species. The elliptical cylinder formula, $\mathrm{V}$ $=\pi(\mathrm{H})$ [Major axis/2 x Minor axis/2], where $\mathrm{H}$ is the plant height, assumes right angles at both the base and crest of the ed. This formula may overestimate plant canopy volume because it does not integrate changing radial distances along the vertical axis of the plant. Shrub canopy volume estimates have also been calculated using the rectangular volume formula ( $\mathrm{H} \times \mathrm{W} \times \mathrm{L}$ ) reported by Uresk et al. (1977). Since plants tend to be bounded by a spherical or elliptical form, the rectangular volume formula may overestimate plant canopy volume by a factor of $\pi$. Conversely, the conical volume formula reported by Bryant and Kothmann (1978), $\mathrm{V}=\left(\pi \mathrm{r}^{2} \mathrm{H}\right) / 3$, where $\mathrm{H}$ is the plant height, may underestimate canopy volume. The conical formula assumes that the junction of the central vertical axis and the
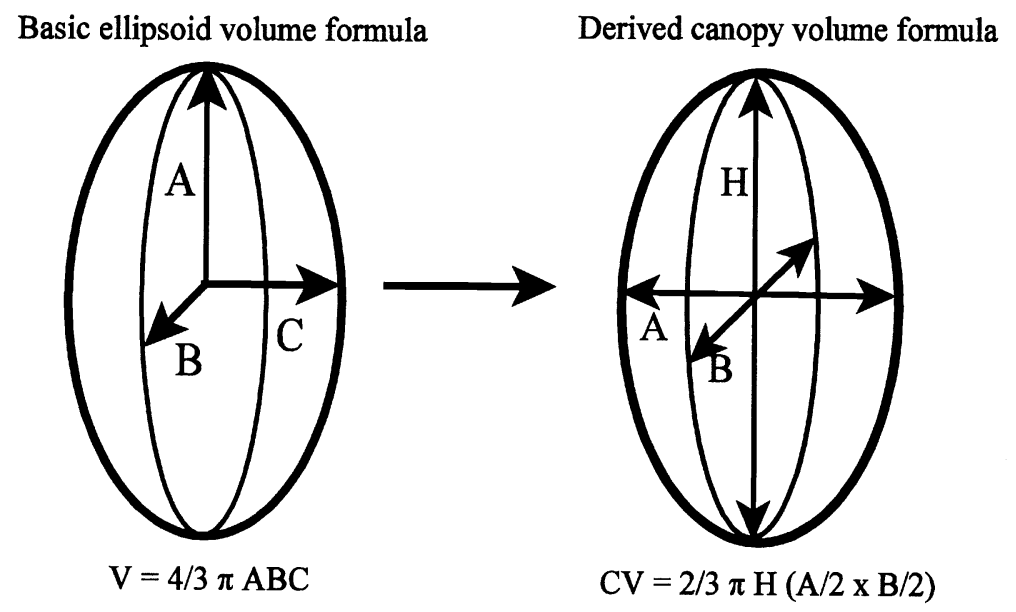

Fig. 1. The canopy volume formula used in this study was derived from the basic ellipsoid volume formula. In the canopy volume $(\mathrm{CV})$ formula, $\mathrm{H}$ is substituted for $\mathrm{A}$ and is the height of the plant from the base to the top of the photosynthetically active material. Both $A$ and $B$ in the $C V$ formula are diameter readings taken at $50 \%$ of the plant height across the plane of photosynthetically active material. Because height and diameter meaurements are used, it is necessary to divide the components of the basic volume formula by 2 so that volume will be properly estimated. ellipsoid volume formula was sensitive ula. Because the ellipsoid form " to the varying sizes and shapes time. repeated observations on sample units: (1) shape for which volume is being estimat-

widest radial plane is a right angle, and that the radial distances are equal across all horizontal axes. Most plants, even when severely hedged, would not meet these requirements, and averaging unequal radial distances of the horizontal axes forces the plant into a contrived canopy shape thus altering the estimate of volume.

The ellipsoid volume formula $[2 / 3 \pi \mathrm{H}$ $(\mathrm{A} / 2 \times \mathrm{B} / 2)]$ used in this study is not subject to the limitations described above (Fig. 1). Changing radial distances along the vertical axes are accounted for within the formula. The formula is elastic and accurately accommodates a wide range of plant shapes and sizes. Specifically, the formula can absorb plant shapes that are non-concentric about the horizontal axis and either compressed or elongated along the vertical axis. Thorne (1998) found that Importantly, growth, utilization, and twig eath do not affect the application of the of plants, consecutive observations closely reflect what has been gained or lost over

The purpose of this study was to describe and evaluate the efficiency, precision, and repeatability of a technique to estimate canopy volume of shrubs. The objectives were to determine if there were significant differences among means of 
among observers, (2) within observers, and (3) between sample periods (means pooled across observers). Secondarily, we asked; could the variability be reduced if observers were trained and the plants were well defined and easy to distinguish?

\section{Materials and Methods}

\section{Study Areas}

This study was conducted in a planeleaf willow (Salix planifolia var. planifolia Pursh) community located on the Paintrock Grazing Allotment (Willow

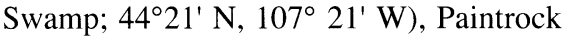
District, Bighorn National Forest, Wyo. in July 1997. The allotment was approximately $24 \mathrm{~km}$ east of Hyattville, Wyo. and ranged in elevation from $2,150 \mathrm{~m}$ to over $3,700 \mathrm{~m}$. Annual precipitation ranged from $380 \mathrm{~mm}$ at the lower elevations to 1,020 $\mathrm{mm}$ at the higher elevations. The shrub component of Willow Swamp (elev. 2,675 m) was actually dominated by bog birch (Betula glandulosa Michx.), but a substantial amount of planeleaf willow was present (Meiman 1996).

A second set of observations were taken among potted planeleaf willows in August 1997 in a common garden at the Greenhouse Facility of the University of Wyoming $\left(41^{\circ} 19^{\prime} \mathrm{N}, 105^{\circ} 35^{\prime} \mathrm{W}\right)$. All plants used in this study were established from stem cuttings of planeleaf willow collected from Willow Swamp in May 1994 for a frequency of clipping study (Thorne 1998).

The observations taken at the Willow Swamp site represented a "worst case" scenario where observers were not trained and the plants were not easily distinguishable. At this site, willows and bog birch grew in close proximity to each other, often with branches intertwined. In other cases, 2 or 3 separately rooted willow plants grew on the same hummock making it difficult to separate plants for the purpose of estimating canopy volume. The observations taken at the garden site represented a "best case" scenario where the plants were easily distinguishable and the observers were more familiar with the technique. Since the plants at the garden were potted separately (i.e., 1 plant per pot) on a 1 x $2 \mathrm{~m}$ grid, distinguishing between plants was not a problem. Further, the same observers were used for both sites and, in effect, had become trained at Willow Swamp for the observations at the Garden site.

\section{Experimental Design}

A completely randomized, repeated measures sample design was used at both sites. At the Willow Swamp site, a base line was established from the northeast corner of a U. S. Forest Service wildlife and livestock exclosure and continued eastward for $100 \mathrm{~m}$. Along the base line, 5 perpendicular sub-transects were established at random distances running south to north. From each sub-transect, one measurement transect was randomly established that ran east to west if the distance up the sub-transect from the base line was an even value or west to east if the value was odd. Along each of the measurement transects, 10 random distances between 0 and $35 \mathrm{~m}$ were selected. Pin flags were placed in the vicinity of each plant along each transect to assist in locating plants during observations. Canopy volume was estimated on the willow nearest to each pin flag along each of the 5 measurement transects.

At the Garden site, five, 10 plant transects were randomly selected from a pool of all possible 10 plant combinations among 200 potted willows. This was done to provide continuity in sampling design between the Garden and Willow Swamp sites.

At both sites, canopy volume measurements along the set of transects, 1 through 5 , were taken twice (sample periods 1 and 2) by each of 4 observers (A, B, C, and D). Each of the 5 transects was considered an observation. Both sample periods were conducted on the same day at both the Willow Swamp and Garden sites on their respective sampling dates. To estimate technique efficiency, the amount of time for each observer to complete a transect was recorded for sample periods 1 and 2 at the Willow Swamp site.

Canopy volume components were measured by taking the height and 2 diameter readings at $50 \%$ of the willow height. Willow height was defined as the distance from the base of the mainstem to the tallest extent of photosynthetically active plant material. Diameter readings were defined as the widest extent of photosynthetically active plant material that intersected a plane passing horizontally through the plant at $50 \%$ of the plant height. The 2 diameter readings were taken at right angles to each other (one parallel and the other perpendicular to the transect line). Willow canopy volume was estimated by applying the height and 2 diameter measurements to a derivative of the basic ellipsoid volume formula,
Canopy Volume $=2 / 3 \pi$ Height $(\mathrm{A} / 2 \mathrm{x}$ $\mathrm{B} / 2$ ), where Height is the distance from the base of the plant to the tallest photosynthetically active material and $\mathrm{A}$ and $\mathrm{B}$ are the diameter readings taken at $50 \%$ of plant height with $\mathrm{B}$ perpendicular to $\mathrm{A}$ (Fig. 1).

The experiment was analyzed using a repeated measures analysis of variance (AOV) with plants as the subject, transects as the within-subject term, and observers and sample period as the between-subject factors (Vonesh and Chinchilli 1997). The model included 2- and 3-way interactions of observers, transects, and sample periods. Plants and transects were random terms. Observer was tested using the transect $\mathrm{x}$ observer interaction as the error term. Sample period was tested with the transect $x$ sample period error term. Observer $\mathrm{x}$ sample period was tested with the error term from the transect $x$ observer $\mathrm{x}$ sample period interaction. Transect $\mathrm{x}$ observer x sample period, observer x plant within transect, and sample period $x$ plant within transect were tested with the residual error term. Since transects were randomly selected, the error terms testing transect, plant within transect, transect $\mathrm{x}$ observer, and transect $\mathrm{x}$ sample period were estimated using the appropriate expected mean squares (Dowdy and Wearden 1991, Vonesh and Chinchilli 1997). Duncan's New Multiple Range (DNMR) Test was used to compare means among and within observers and sample periods (Duncan 1955, Dowdy and Wearden 1991) when appropriate. All mean separations were conducted with an overall $\alpha$ of 0.05 and 12 degrees of freedom.

To compare the consistency and precision among and within observers, coefficients of variation were calculated by sample period for each observer. Since the coefficient of variation is a measure of the internal variability of an estimate, differences among sequential coefficient values for the same sample unit reflect a shift in the degree of observer error. Thus, smaller coefficient of variation values were interpreted to indicate greater precision in an estimate. Consistency across sample periods was considered to be explained by the degree of similarity in coefficient of variation values when AOV indicated non-significance.

Sample size calculations were conducted to estimate the number of 10 plant transects required to achieve a sampling precision (E) of $\pm 10,20$, or $30 \%$ of the mean 
total canopy volume of the willow population at the study sites with confidence intervals of 80,90 , or $95 \%$. Desired sample sizes were estimated using the average coefficient of variation for each of the 4 observers estimated for sample periods 1 and 2 at each study site. The formula used to estimate sample size was: $n=t^{2} C^{2} / E^{2}$ where $t$ is the critical $t$-value evaluated at $\alpha / 2$ and $\infty$ degrees of freedom; CV is the coefficient of variation; and $E$ is the desired sampling precision (Zamora 1981).

\section{Results}

\section{Willow Swamp Site}

At the Willow Swamp site, differences among transects, and transect $\mathrm{x}$ observer, observer $\mathrm{x}$ sample period, and transect $\mathrm{x}$ observer $\mathrm{x}$ sample period interactions were not significant $(P=0.296,0.846,0.151$, and 0.069 , respectively). Observer A's estimate of mean canopy volume increased by $19 \%$ between sample periods 1 and 2, while the coefficients of variation changed from 26 to $29 \%$, respectively (Table 1). Conversely, estimated mean canopy volume decreased by 3,19 , and $6 \%$ between sample periods 1 and 2 for observers B, C, and D, respectively (Table 1). Coefficients of variation also increased between sample periods 1 and 2 for observers B, C, and D (Table 1).
Observers varied significantly $(\mathrm{P}=$ 0.009 ) in their estimates of canopy volume at the Willow Swamp site. However, while the average canopy volume estimated by observer B was significantly different from the other observers, estimates among observers A, C, and D were not different (Table 1). The transect $\mathrm{x}$ sample period interaction was not significant $(\mathrm{P}=$ 0.493 ) for Willow Swamp. When mean canopy volume was pooled across observers, sample period $1(81,043 \pm$ $\left.6,626 \mathrm{~cm}^{3} \mathrm{SE} ; \mathrm{n}=20\right)$ did not vary $(\mathrm{P}=$ $0.814)$ from sample period $2(79,599 \pm$ $7,786 \mathrm{~cm}^{3} \mathrm{SE} ; \mathrm{n}=20$ ).

The average time to measure canopy volume along a transect decreased from sample period 1 to 2 for all observers. Observer D had the largest decrease averaging 17.2 minutes $(\mathrm{SD}=5.07)$ per transect during sample period 1 compared to 9.3 minutes $(\mathrm{SD}=1.3)$ during sample period 2. Observers $\mathrm{A}, \mathrm{B}$, and $\mathrm{C}$ averaged $11.1 \pm 1.03,8.4 \pm 2.1$, and $13.2 \pm 3 \mathrm{~min}-$ utes per transect to measure canopy volume during sample period 1, respectively. During sample period 2, the average time per transect decreased to $9.4 \pm 0.5,7.6 \pm$ 2.1 , and $9.6 \pm 0.5$ minutes for observers $A$, $\mathrm{B}$, and $\mathrm{C}$, respectively. The average time per transect among all observers for sample period 1 was 12.5 minutes $(\mathrm{SD}=3.7$ ) and decreased to 9.3 minutes $(\mathrm{SD}=1.3)$ in sample period 2 .

\section{Garden Site}

At the garden site, differences among transects, and transect $\mathrm{x}$ observer, observer $\mathrm{x}$ sample period, and transect $\mathrm{x}$ observer $\mathrm{x}$ sample period interactions were not significant $(\mathrm{P}=0.493,0.604,0.06$, and 0.163, respectively). Mean canopy volume decreased between sample periods 1 and 2 by 2,10 , and $5 \%$ for observers $\mathrm{A}, \mathrm{B}$, and $\mathrm{D}$, respectively (Table 2 ). Conversely, the estimated mean canopy volume increased by nearly $17 \%$ for observer C. Coefficients of variation at the Garden site remained constant at $23 \%$ for observer $\mathrm{A}$, increased for observers B and D, and decreased for observer $\mathrm{C}$.

Observers varied significantly $(\mathrm{P}<$ 0.001 ) in their estimate of canopy volume for the Garden site (Table 2). Mean canopy volume estimates of observers A and $\mathrm{D}$ were similar and significantly different from the average volume estimates of observers $\mathrm{B}$ and $\mathrm{C}$ which were also similar. At the Garden site, the transect $\mathrm{x}$ sample period interaction was not significant $(\mathrm{P}=0.854)$. When canopy volume estimates were pooled across observers, sample period $1\left(159,187 \pm 24,993 \mathrm{~cm}^{3}\right.$ $\mathrm{SE} ; \mathrm{n}=20)$ did not vary $(\mathrm{P}=0.510)$ from sample period $2\left(157,512 \pm 21,060 \mathrm{~cm}^{3}\right.$ $\mathrm{SE} ; \mathrm{n}=20$ ).

Table 1. Mean canopy volume $\left(\mathrm{cm}^{3}\right)$ for each observer by transect and sample period for measurements taken at Willow Swamp, 17 Jul. 1997.

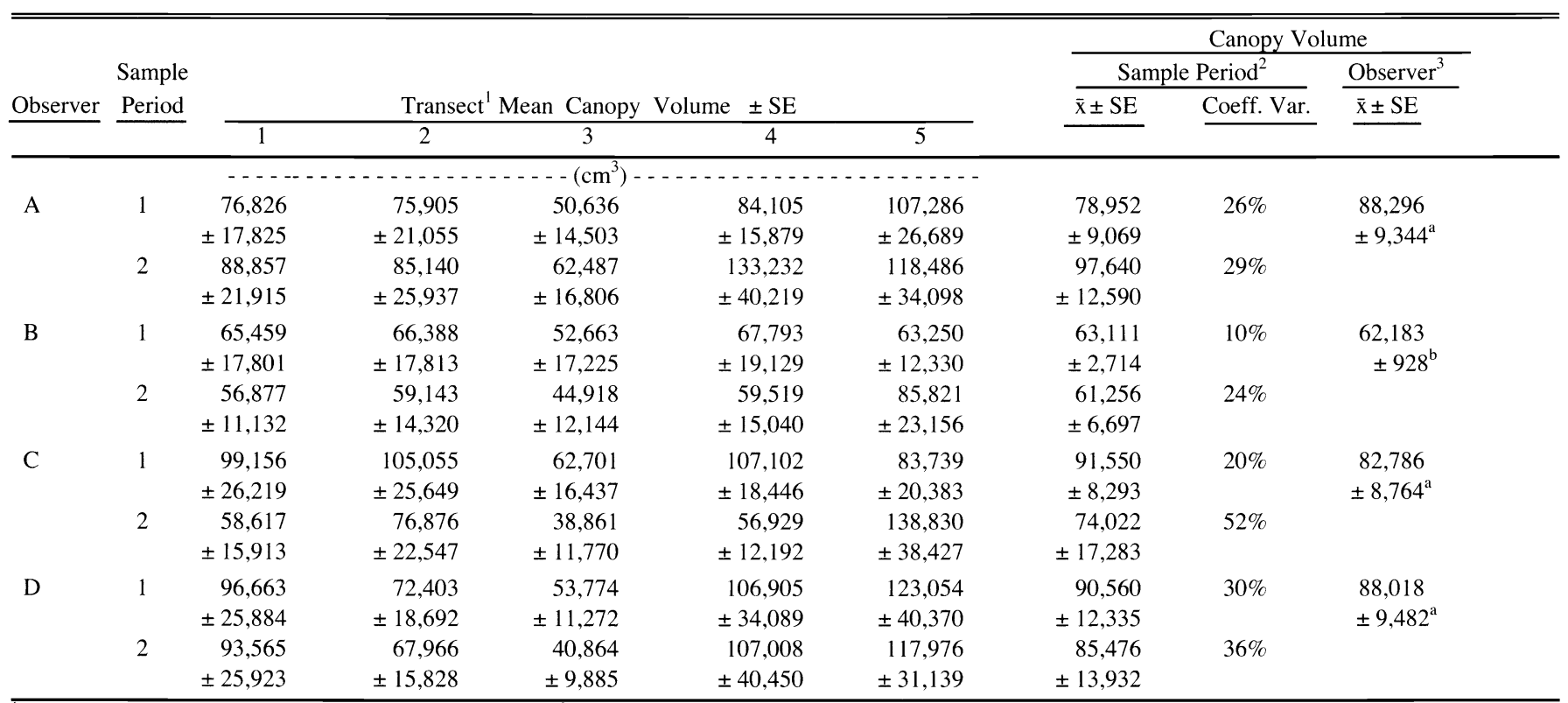

\footnotetext{
${ }^{\mathrm{T}}$ Transect mean canopy volume \pm standard error of the mean $\left(\mathrm{cm}^{3}\right), \mathrm{n}=10$; within observer means at transect level were not significantly different $(\mathrm{P}>0.05)$. ${ }^{2}$ Sample period mean canopy volume \pm standard error of the mean $\left(\mathrm{cm}^{3}\right), \mathrm{n}=5$ (average of 5 transects); within observer means at the sample period level were not significantly different $(\mathrm{P}>0.05)$

${ }^{3}$ Mean canopy volume \pm standard error of the mean $\left(\mathrm{cm}^{3}\right)$ by observer, $\mathrm{n}=2$ (average across sample periods); means among observers were significantly different $(\mathrm{P}<0.05)$, likelet-
} tered means were not different using Duncan's New Multiple Range Test. 
Table 2. Mean canopy volume $\left(\mathrm{cm}^{3}\right)$ for each observer by transect and sample period for measurements taken at the Garden site, 29 Aug. 1997.

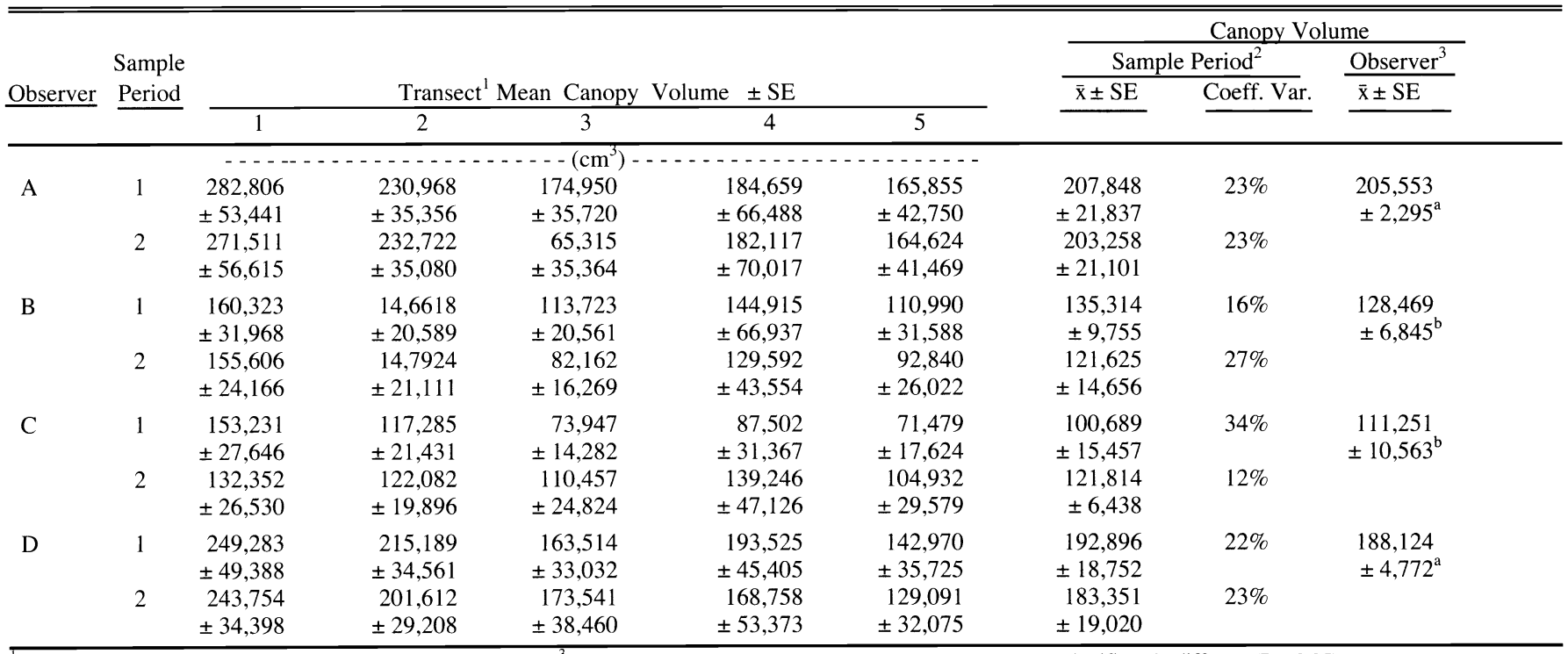

Transect mean canopy volume \pm standard error of the mean $\left(\mathrm{cm}^{3}\right), \mathrm{n}=10$; within observer means at transect level were not significantly different $(\mathrm{P}>0.05)$.

${ }^{2}$ Sample period mean canopy volume \pm standard error of the mean $\left(\mathrm{cm}^{3}\right), \mathrm{n}=5$ (average of 5 transects); within observer means at the sample period level were not significantly different $(\mathrm{P}>0.05)$.

${ }^{3}$ Mean canopy volume \pm standard error of the mean $\left(\mathrm{cm}^{3}\right)$ by observer, $\mathrm{n}=2$ (average across sample periods); means among observers were significantly different $(\mathrm{P}<0.05)$, like lettered means were not different using Duncan's New Multiple Range Test.

\section{Sample Size}

The average coefficient of variation among both sample periods for all observers was $28 \%( \pm 12.25 \mathrm{SD})$ for Willow Swamp and $22.5 \%$ ( \pm 6.61 SD) for the Garden site. Our estimates of sample size were evaluated with the variation based on 5 transects comprised of 10 plants each. Consequently, the sample sizes reported here should be considered as the minimum estimated number of transects with 10 plants each required to meet experimental design restrictions. At Willow Swamp, sample sizes ranged between 2 and 31 transects depending on the level of desired precision and confidence level (Table 3). For the Garden site, the largest estimated sample size was 20 transects required to obtain an estimate within $\pm 10 \%$ of the population mean at the $95 \%$ confidence level (Table 3 ). The minimum viable number of transects estimated to be required at the Garden site was 2 (one transect does not provide an estimate of variability and, thus, is not a viable sample size).

\section{Discussion}

At Willow Swamp, 3 of the 4 observers did not have experience with this technique before taking measurements. Training included only a brief introduction on the identification of: a) the measure- ment plant, b) its photosynthetically active material, and c) where to place the measuring rods. Sampling error was compounded when several willows occurred on the same hummock together or with bog birch plants. Consequently, it was possible for an observer to mistakenly measure more or less plant, or a different plant at the second sample period. At the Garden site, these sources of observer error were controlled. Observers had gained experience from the Willow Swamp measurements and plant identification problems were eliminated.

\section{Consistency, Precision, and Efficiency}

The lack of significance in the AOV among the interaction terms at both sites

Table 3. Estimated number of transects of 10 plants each required to achieve sampling precision (E) of $\pm 10,20$, and $30 \%$ of the mean total canopy volume of the willow populations at the Willow Swamp and Garden sites at confidence levels of 80,90 , and $95 \%$.

\begin{tabular}{|c|c|c|c|c|}
\hline \multirow[b]{2}{*}{ Site } & \multirow[b]{2}{*}{ Sampling Precision } & \multicolumn{2}{|c|}{ Confidence Level } & \multirow[b]{2}{*}{$\overline{95 \%}$} \\
\hline & & $80 \%$ & $90 \%$ & \\
\hline \multirow[t]{4}{*}{ Willow Swamp $(\mathrm{CV}=28 \% \pm 12.35)^{1}$} & -------(\%)----- & \multicolumn{3}{|c|}{ - (Sample Size)----- } \\
\hline & \pm 10 & 13 & 22 & 31 \\
\hline & \pm 20 & 4 & 6 & 8 \\
\hline & \pm 30 & 2 & 3 & 4 \\
\hline \multicolumn{5}{|l|}{ Garden $(\mathrm{CV}=22.5 \% \pm 6.61)$} \\
\hline & \pm 10 & 9 & 14 & 20 \\
\hline & \pm 20 & 3 & 4 & 5 \\
\hline & \pm 30 & $1^{2}$ & 2 & 3 \\
\hline
\end{tabular}

${ }^{\mathrm{C} V}=$ coefficient of variation; coefficients presented in this table are the average $\mathrm{CV}$ of observers for both sample periods at each site $(n=8)$.

${ }^{2}$ Note that 1 transect does not provide an estimate of variability and, thus, is not a viable sample size. 
between mean estimates $(19 \%)$ and the increase in coefficients of variation $(20$ $52 \%$ ) for this observer.

At the Garden site, the within observer consistency and precision improved for all observers. Coefficient of variation values were lower at the Garden site than at Willow Swamp in 5 of 8 observations among observers. More importantly, differences in coefficient of variation values between sample periods for observers B, $\mathrm{C}$, and D were smaller than at Willow Swamp. For observer A, however, coefficient of variation values remained constant at $23 \%$ between sample periods at the Garden site.

Efficiency is a function of both the precision and time required to obtain a reliable estimate. As the variation in the experimental material and observer error increases, sample size must increase rapidly to bring the precision of the estimate to within a desired percentage of the population mean at a given level of confidence. The more samples required to achieve a desired level of precision, the more time required to obtain the estimate. We found, under difficult conditions for estimating canopy volume, that the average coefficient of variation was about $28 \%$. With this level of precision, we estimated between 2 and 31 transects would be required depending on the level of desired precision $( \pm 10,20$, and $30 \%)$ and confidence $(80,90$, and $95 \%)$. These are not unreasonably large sample sizes given that the average time estimated to complete a transect was between 9 and 13 minutes. Consider also, that the precision increased and the estimated sample size decreased when the shrubs were well defined and easily distinguishable.

Other techniques commonly used to estimate shrub cover or volume do not appear to be as precise or efficient by comparison. For example, coefficients of variation for shrub cover estimated by the line-intercept method in different community types have ranged from 18.5 to $86.8 \%$ (Heady et al. 1959, Kinsinger et al. 1960). Estimated sample sizes for the line-intercept method have varied between 14 and 290 transects (Heady et al. 1959, Kinsinger et al. 1960) with each transect requiring, on average, 16 minutes to complete (Heady et al. 1959). Zamora (1981) proposed a method using a $3-\mathrm{m}^{3}$ frame to estimate canopy volume based on midpoint averages of eight volume size classes. He reported coefficients of variation of
63 to $168 \%$ for shrub communities in 3 different grand fir [Abies grandis (Douglas ex D. Don in Lambert) Lindley] clear cuts in north-central Idaho. Subsequently, he estimated that between 1,084 and seven, $3-\mathrm{m}^{3}$ plots were required to achieve a desired level of precision and confidence $( \pm 10$ and $30 \%$ of the mean at 95 and $80 \%$ confidence level, respectively). Although Zamora (1981) did not estimate time per plot directly, he did report that, under highly diverse composition and complex structure, 50 plots required 3 man hours to complete.

\section{Differences Among Observers}

In most cases, while not desirable, observers frequently vary in estimates of the same sample unit. Our results confirm that observers can vary in their mean estimates. However, observer differences were not as pronounced at Willow Swamp as they were at the Garden site. Specifically, at Willow Swamp, mean estimates by observers A, C, and D were within 0.3 to $6 \%$ of each other and were not statistically different. Observer B, however, differed by 30,29 , and $25 \%$ from observers A, D, and C, respectively. Thus, observer B accounted for most of the differences among observers at Willow Swamp. Conversely, at the Garden site, mean estimates of willow volume by pairs of observers who were not statistically different were more divergent. For example, observers B and C were $13 \%$ different from each other while observers $A$ and $D$ were less than $9 \%$ different.

The divergence of agreement on the mean canopy volume estimates among observers may have been the result of training. Smith (1944) found that differences among observers were greater after a week's training. He suggested that this was caused by a general inclination among observers to become more conservative as a result of discussion and comparison of estimates. This may well have been a factor in our study. Although effort was made to restrict comparisons among mean estimates at both sites, discussion among observers was inevitable. Note, however, that although training seemingly contributed to a greater divergence in mean estimates among observers at the Garden site, within observer mean estimates were less variable and were not significantly different between sample periods.

Importantly, there was no transect by sample period interaction among observers. Moreover, the estimate of mean canopy volume pooled across observers did not vary between sample periods. This suggests that canopy volume estimates can be made by an individual managing a local area, or by a team of individuals sampling over a large geographical area with the same level of precision.

\section{Conclusions}

Conclusions are: a) Willow canopy volume estimates will likely vary between individuals using this technique. b) Estimates of canopy volume made by a single individual will be consistent and precise. Moreover, differences in canopy volume estimates made by a single individual appear to decrease with training. c) When observations of each individual are pooled, estimates of canopy volume appear to be reliable and precise supporting a team concept to monitoring broad geographical areas using this technique. Mean canopy volume did not vary significantly across sample periods when estimates were pooled among observers.

\section{Management Implications and Recommendations}

In using the canopy volume method described here, it is recommended that managers first clearly define management objectives for a site or sites. This will help define the desired sampling intensity required to monitor trends toward meeting stated objectives. Permanent transects should be placed randomly throughout the community. Plants along the transects should be randomly located and permanently marked for identification. The basal perimeter of each plant should be clearly defined. This can be accomplished by wrapping colored wire or plastic ties around the outside basal stems of the shrub (Thorne 1998). Permanently marking the location and basal perimeter of each plant should improve the precision of consecutive canopy volume estimates.

Using this method, managers can better describe and monitor trends in the structural diversity of shrub communities. This canopy volume technique appears to be sensitive to changes in plant size over short time intervals (Thorne 1998), so it can be used to evaluate annual impacts to 
shrub communities such as herbivory, disease, drought, and various land uses. Other uses might include evaluating wildlife habitat quality and forage production (Taylor 1986, Manoukian 1994).

In monitoring our rangeland resources, a methodology that is efficient, precise, and repeatable is clearly desirable. This canopy volume technique can be applied with minimal training and is precise, efficient, and repeatable. It can also be consistently applied by an individual observer as well as by a team of observers to sample larger geographical areas.

\section{Literature Cited}

Bauer, H.L. 1936. Moisture relations in the chaparral of the Santa Monica Mountains, California. Ecol. Monogr. 6:409-454.

Bryant, F.C. and M.M. Kothmann. 1979. Variability in predicting edible browse from crown volume. J. Range Manage. 32:144-146.

Creamer, W.H. IV. 1991. Prediction of available forage production of big sagebrush. M.S. Thesis, Montana State Univ., Bozeman, Mont.

Cooper, C.F. 1957. The variable plot method for estimating shrub density. J. Range Manage. 10:111-115.

Daubenmire, R. 1959. A canopy-coverage method of vegetational analysis. Northwest Sci. 33:43-64.

Daubenmire, R. 1968. Plant communities-a textbook of synecology. Harper and Row, N.Y.
Dowdy, S., and S. Wearden. 1991. Statistics for research. 2nd ed. John Wiley \& Sons, N.Y.

Duncan, D.B. 1955. Multiple range and multiple F tests. Biometrics 11:1-42.

Fisser, H.G. 1961. Variable plot, square foot plot, and visual estimate of shrub crown cover measurements. J. Range Manage. 14:202-207.

Heady, H.F., R.P. Gibbens, and R.W. Powell. 1959. A comparison of the charting, line intercept, and line point methods of sampling shrub types of vegetation. J. Range Manage. 12:180-188.

Johnston, A. 1957. A comparison of the line interception, vertical point quadrat, and loop methods as used in measuring basal area of grassland vegetation. Can. J. Plant Sci. 37:34-42.

Kinsinger, F.E., R.E. Eckert, and P.O. Currie. 1960. A comparison of the lineinterception, variable-plot and loop methods as used to measure shrub-crown cover. J. Range Manage. 13:17-21.

Lyon, J.L. 1968. Estimating twig production of serviceberry from crown volumes. J. Wildl. Manage. 32:115-119.

Manoukian, M.E. 1994. Evaluation of tall willows (Salix Spp.) within a livestock grazing allotment in southwest Montana. M.S. Thesis, Montana State Univ., Bozeman, Mont.

Meiman, P.J. 1996. Effects of large ungulate herbivory on willow (Salix) in mountain rangelands of northern Wyoming. M.S. Thesis, Univ. Wyoming, Laramie, Wyo.

Myers, L.H. 1989. Riparian area management: Inventory and monitoring riparian areas. U.S. Dept. Int., Bur. Land Manage.,TR 1737-3 Denver, Colo.
Nelson, E.W. 1930. Methods of studying shrubby plants in relation to grazing. Ecol. 11:764-769.

Parker, K.W. 1951. A method for measuring trend in range condition on national forest ranges. U.S. Forest Serv., Washington, D.C.

Peek, J.M. 1970. Relation of canopy area and volume to production of three woody species. Ecol. 51:1098-1101.

Pickford, G.D., and G. Stewart. 1935. Coordinate method of mapping low shrubs. Ecol. 16:257-261.

Rittenhouse, L.R. and F.A. Sneva. 1977. A technique for estimating big sagebrush production. J. Range Manage. 30:68-70.

Smith, A.D. 1944. A study of the reliability of range vegetation estimates. Ecol. 25:441-448.

Taylor, D.M. 1986. Effects of cattle grazing on passerine birds nesting in riparian habitat. J. Range Manage. 39:254-258.

Thorne, M.S. 1998. Effects of large ungulate herbivory on willow (Salix) canopy volume on mountain rangelands of northern Wyoming. M.S. Thesis, Univ. Wyoming, Laramie, Wyo.

Uresk, D.W., R.O. Gilbert, and W.H. Rickard. 1977. Sampling big sagebrush for phytomass. J. Range Manage. 30:311-314.

Vonesh, E.F., and V.M. Chinchilli. 1997. Linear and nonlinear models for the analysis of repeated measurements. Marcel Dekker, Inc. New York, N.Y.

Zamora, B.A. 1981. An approach to plot sampling for canopy volume in shrub communities. J. Range Manage. 34:155-156. 